\title{
Human touch in digital education-a solution
}

\author{
Mehul Sinha $^{1} \cdot$ Vikas Agarwal $^{2} \cdot$ Latika Gupta $^{2}$
}

Received: 25 September 2020 / Revised: 25 September 2020 / Accepted: 5 October 2020 / Published online: 9 October 2020

(C) International League of Associations for Rheumatology (ILAR) 2020

\section{Dear Editor,}

Ahmed et al. have raised a timely and pertinent issue of a switch to a virtual model of education, including Massive Open Online Courses (MOOCs) in Rheumatology to cope with these unprecedented times. As they rightly discuss, a lack of emotional connection may be a major impediment to delivering education by this approach [1]. This may translate into high drop-out rates. However, recent insights into behaviour and personality patterns and continuing advances in technology may provide a solution to overcome the challenges posed by one-way communication.

While the traditional xMOOC ( $\mathrm{x}$ for extended) model emphasises on learning through video presentations and short quizzes and testing, the evolving role of social media in academia has shifted the emphasis on the cMOOC (c for connectivity) model. The latter lays greater emphasis on creativity, autonomy and knowledge creation, wherein the individual instructor is replaced by a group of people learning together, the student being the teacher and vice versa [2]. The availability of new open online learning resources in the Covid-19 era adds to the opportunity to engage in such collaborative exercises while enhancing one's skill base. Numerous MOOCs are free of charge and offer extended participation to a large number of individuals, including students and teachers. The EULAR and ACR have made significant contributions in developing e-learning opportunities with updated literature with utility for training and practice alike. A EULAR network study states that $84 \%$ of the young rheumatologists would be interested in attending online case discussions, training courses and webinars [3]. In peri-pandemic times when patient visits are reduced to a minimum, MOOCs may be useful to impart clinical skills using virtual patient simulation [4]. MOOCs may also be used to deliver allied health services such

Latika Gupta

drlatikagupta@gmail.com

Kasturba Medical College, Mangalore, Karnataka, India

2 Department of Clinical Immunology and Rheumatology, Sanjay Gandhi Postgraduate Institute of Medical Sciences, Lucknow, India as exercise, nutrition and mindfulness advice when appropriately designed for patients [5].

The motivation to enrol in MOOCs may vary, from the keen desire to learn and build on the existent knowledge base, curiosity about MOOCs, to develop a support networked professional learning, or as a personal challenge [6]. Moreover, their flexibility and self-paced learning principle is a unique advantage over the conventional classroom model. Virtual connectivity has made the world a smaller place, and these MOOCs may allow interested students to acquire new skills from well-established professors from premier institutes even without enrolling in a top-notch university. Self-regulated learning plays a major role in improving the outcomes in course completion. It entails a stringent practice, including goal setting, efficient time management, progress monitoring, peer support and motivation from instructors with a positive environment for good learning outcomes [7]. Learners with a self-regulated approach are more likely to have higher watch hours and revisit the course materials for future reference [8].

Poor didactic communication in MOOCs may translate into a feeble understanding of the topic, inability to resolve doubts, and poor trust and low self-confidence to reach out to the teacher [9]. Since online learning has become such a staple in today's pandemic situation, the emphasis may be shifted from content and design of the course to support, guidance and feedback from instructors and peers in a group learning approach as furthered by cMOOCs. Psychometric modelling may analyse learner proficiency, motivation and personality type to derive an algorithm-driven personalised understanding of the suggested courses to improve the likelihood of course completion rates [10].

Meanwhile, virtual conferences, social media platforms and post-publication peer-review continue to contribute to information dissemination a collective learning experience [11, 12]. Amid a surge in literature, it is also vital to avoid misinformation $[13,14]$. Collaborative networks between scholarly journals and academicians can together have a rapid and powerful social media presence with wide dissemination of credible information. Therefore, these reforms might be able to bring a more human touch to online learning and thus 
improving the mentor-mentee bond, which will help in improving the learning outcomes from digital learning.

Authors' contribution All authors were involved in writing and reviewing the manuscript for critical intellectual inputs.

\section{Compliance with ethical standards}

Conflict of interest The authors declare that they have no conflict of interest.

Ethics clearance Not applicable.

Consent to participate Not applicable.

Consent to publication Not applicable.

Code availability Not applicable

\section{References}

1. Ahmed S, Zimba O, Gasparyan AY (2020) Moving towards online rheumatology education in the era of COVID-19. Clin Rheumatol [Internet]. Available from: https://doi.org/10.1007/s10067-02005405-9

2. Fidalgo-Blanco Á, Sein-Echaluce ML, García-Peñalvo FJ (2016) From massive access to cooperation: lessons learned and proven results of a hybrid xMOOC/cMOOC pedagogical approach to MOOCs. Int J Educ Technol High Educ [Internet] 13(1):24. Available from: https://doi.org/10.1186/s41239-016-0024-z

3. Najm A, Kostine M, Pauling JD, Ferreira AC, Stevens K, Smith E et al (2020) Multidisciplinary collaboration among young specialists: results of an international survey by the emerging EULAR network and other young organisations. RMD Open [Internet] 6(2):e001398. Available from: http://rmdopen.bmj.com/content/6/ 2/e001398.abstract

4. Berman $A H$, Biguet $G$, Stathakarou N, Westin-Hägglöf B, Jeding $\mathrm{K}$, McGrath C et al (2017) Virtual patients in a behavioral Medicine Massive Open Online Course (MOOC): a qualitative and quantitative analysis of participants' perceptions. Acad Psychiatry [Internet]. [cited 2020 Sep 5];41(5):631-41. Available from: https://link.springer.com/article/10.1007/s40596-017-0706-4

5. Tropé S, Cohen JD, Beauvais C, Poivret D, Saraux A, VACHER D, Barkatz H, Lacoste P, Weill V, Thibaud G (2017) Creation of the first massive open online course for patients with rheumatoid arthritis [abstract]. Arthritis Rheumatol 69 (suppl 10). https:// acrabstracts.org/abstract/creation-of-the-first-massive-open-onlinecourse-for-patients-with-rheumatoid-arthritis/. Accessed 21 Sept 2020

6. Chen B, Fan Y, Zhang G, Liu M, Wang Q (2020) Teachers' networked professional learning with MOOCs. Kovanovic V, editor. PLoS One [Internet]. [cited 2020 Sep 5];15(7):e0235170. Available from: https://doi.org/10.1371/journal.pone.0235170

7. Barnard-Brak L, Lan WY, Paton VO (2010) Profiles in selfregulated learning in the online learning environment. Int Rev Res Open Distance Learn 11(1):61-80. Available from: https:// doi.org/10.19173/irrodl.v11i1.769

8. Kizilcec RF, erez-Sanagustín MP, Maldonado JJ (2017) Selfregulated learning strategies predict learner behavior and goal attainment in Massive Open Online Courses. [cited 2020 Sep 5]; Available from: https://doi.org/10.1016/j.compedu.2016.10.001

9. Ryan AM, Pintrich PR, Midgley C (2001) Avoiding seeking help in the classroom: who and why? Educ Psychol Rev [Internet] [cited 2020 Sep 5];13(2):93-114. Available from: https://link.springer. com/article/10.1023/A:1009013420053

10. Abbakumov D, Desmet P, Van den Noortgate W (2020) Psychometrics of MOOCs: measuring learners' proficiency. Psychol Belg [Internet] [cited 2020 Sep 5];60(1):115-31. Available from: /pmc/articles/PMC7243831/?report=abstract Available from: https://doi.org/10.5334/pb.515

11. Haldule S, Davalbhakta S, Agarwal V, Gupta L, Agarwal V (2020) Post-publication promotion in rheumatology: a survey focusing on social media. Rheumatol Int [Internet]. Available from: https://doi. org/10.1007/s00296-020-04700-7

12. Ahmed S, Gupta L (2020) Perception about social media use by rheumatology journals: survey among the attendees of IRACON 2019. Indian J Rheumatol [serial online] [cited 2020 Sep 23];15: 171-4. Available from: http://www.indianjrheumatol.com/text.asp? 2020/15/3/171/286216

13. Goel A, Gupta L (2020) Social Media in the Times of COVID-19. J Clin Rheumatol 26(6):220-3.Available from: https://doi.org/10. 1097/RHU.000000000000150

14. Garg S, Singh RR (2019) Addressing the unmet needs in medical training for alarmingly widening demand-supply gap in rheumatic diseases: a tale of two countries. Indian J Rheumatol [serial online] [cited 2020 Sep 23];14:167-71. Available from: http://www. indianjrheumatol.com/text.asp?2019/14/3/167/266933

Publisher's note Springer Nature remains neutral with regard to jurisdictional claims in published maps and institutional affiliations. 